\title{
Technokracja i demagogia
}

DOI: $10.35757 /$ CIV.2010.12.09

Na pierwszy rzut oka może się wydawać, iż tytuł niniejszego tekstu stanowi contradictio in adiecto - sztuczne połaczenie dwóch wzajemnie wykluczających się pojęć. Technokracja i technika powszechnie kojarza się z precyzją rozumowania, ścisłościa i konsekwentnym poszukiwaniem najlepszego rozwiąania ściśle określonego problemu. Demagogia zaś wiązana jest $z$ mglistym i celowo nieprecyzyjnym obiecywaniem „gruszek na wierzbie”. Pozornie trudno więc o większą rozbieżność, jednak, jak będę się starał argumentować, demagogia stanowi nie tylko jedna $z$ możliwych, ale wręcz nawet najbardziej prawdopodobna $z$ konsekwencji technokracji. Jest tym samym realnym zagrożeniem dla współczesnego życia politycznego.

Globalizacja i wszystkie związane $z$ tym procesy unifikujące, a jednocześnie zwiększające nieustannie, i tak już niemały, poziom komplikacji procesów społecznych i politycznych powodują, w pewnym sensie naturalna, skłonność do oddania władzy tym, którzy są $\mathrm{w}$ stanie ten chaos ogarnać i uporządkować. A więc przede wszystkim tym, którym zawdzięczany wysoki poziom naszej cywilizacji: uczonym i technikom. Wobec kryzysu wszelkich ideologii oraz odrzucenia autorytetu religii i filozofii pozostaje tylko jedna siła, której dokonania sa bezsporne - technologia. Paradoksalnie nie przeszkadza w tym nawet coraz powszechniejsze przekonanie

Stanisław Gatkowski - absolwent Wydziału Filozofii Katolickiego Uniwersytetu Lubelskiego, doktor habilitowany w zakresie filozofii, profesor Krakowskiej Akademii im. Andrzeja Frycza Modrzewskiego, kierownik Katedry Filozofii Polityki. Autor m.in. Rozwój i odpowiedzialność. Antropologiczne podstawy koncepcji wychowania moralnego (2003). 
o kryzysie cywilizacji technicznej, ujawniające się chociażby w zagrożeniach ekologicznych - w końcu jeżeli technologia jest przyczyna kryzysu, od niej też należy żądać środków naprawczych.

Łączy się $z$ tym założenie, iż wysokie kompetencje zawodowe i intelektualne sa synonimem ogólnej doskonałości (w tym moralnej) ich podmiotu. „Sokratejskie utożsamienie wiedzy i cnoty odegrało ważną rolę w historii. Było podstawą Platońskiej koncepcji filozofa-władcy i tak długo trwającego w starożytności oddania dla rozumu"1.

Dzięki temu połączeniu niezwykle wysoki autorytet nauki oraz wielka skuteczność techniki przenoszą się na uznanie i autorytet ludzi, którzy zdobyli kompetencje w tych dziedzinach. To leży u podłoża idei technokracji: rządów sprawowanych - dla powszechnego szczęścia - przez mistrzów rozumu: technologii i nauki. Dzisiaj, wraz $z$ rozwojem nauk społecznych, idea ta przybiera nieco odmienna postać, choć wciąż czerpie $z$ tego samego Platońskiego źródła. Jest nią przekonanie, że należy oddać rządy ludziom najbardziej do tego przygotowanym: biurokratom i urzędnikom.

\section{Technokratyzm i demokracja}

„Technokracja - koncepcja ustroju społecznego, w którym władzę sprawowaliby technicy, eksperci, organizatorzy i kierownicy produkcji”" wywodzi się niezwykle często ze zmęczenia polityka, postrzegania jej jedynie jako jałowego sporu, prowadzonego przez niekompetentnych amatorów (będących jednocześnie fanatykami i/lub cynikami myślacymi tylko o własnej korzyści). Stąd przekonanie, że administrowanie można i powinno się „zawsze jasno oddzielić od polityki, i że jeśli się tego dokona, to nie ma takich

\footnotetext{
1 G. Tinder: Myślenie polityczne. Odwieczne pytania, przekład A. Dziurdzik, Wydawnictwo Naukowe PWN, Warszawa 2003, s. 165.

2 M. Szymczak (red.): Słownik języka polskiego, Wydawnictwo Naukowe PWN, Warszawa 1981, s. 487.
} 
spraw - albo jest ich bardzo niewiele - którymi zajmuja się politycy, a których administracja nie załatwiłaby lepiej. [...] władza mogłaby być sprawowana znaczniej lepiej przez tych, którzy rzeczywiście zajmuja się sprawami państwa. [...] "tylko głupcy będa się spierać o najlepszą formę władzy; ta jest najlepsza tam, gdzie rządzą urzędnicy"”3.

Technokracja polega więc na oddaniu władzy specjalistom. Rola specjalisty polega zaś na skoncentrowaniu się na jednym obszarze wiedzy, przesianiu wszystkich dostepnych danych, wyeliminowaniu tych, które nie maja znaczenia dla rozważanego problemu oraz wykorzystaniu tego, co zostało, do jego rozwiazania ${ }^{4}$. W sposób oczywisty jest to najlepsze podejście przy rozwiazywaniu problemów technicznych. Nie sprawdza się jednak tam, gdzie kwestia wydajności nie jest najważniejsza, a rola techniki maleje (na przykład w życiu rodzinnym, edukacji czy szerzej: w relacjach międzyludzkich). W sytuacjach jednak, gdy mamy do czynienia $z$ wyborami światopoglądowymi lub gdy wymagania skuteczności wchodza $\mathrm{w}$ konflikt $\mathrm{z}$ już uznanymi wartościami, technokracja staje się niebezpieczna, gdyż przedkłada kryteria obowiąujace $\mathrm{w}$ technice (to znaczy skuteczność) ponad wszystkie inne.

Przyczyna tego jest między innymi fakt, że rozwiązania techniczne nie sa obojętne względem sfery wartości. Technika i nauka jest „ślepa aksjologicznie”, jej rozwój rządzi się swoimi prawami, które niekoniecznie musza prowadzić w kierunku korzystnym dla ludzkości. Co więcej - jej odkrycia nie są neutralne względem naszego życia, ale wręcz $\mathrm{w}$ pewnym sensie pozostają wobec niego nadrzędne i dotyczą każdego aspektu ludzkiej aktywności. Jak pisał Neil Postman: „Któż mógł się spodziewać, że automobil będzie nam podpowiadał, jak mamy prowadzić swoje życie towarzyskie i seksualne? Że zmieni nasze plany w stosunku do naszych

\footnotetext{
3 B. Crick: W obronie polityki, przekład A. Waśkiewicz, Wydawnictwo Naukowe PWN, Warszawa 2004, s. 144.

4 Por. N. Postman: Technopol. Triumf techniki nad kultura, przekład A. Tanalska-Dulęba, Wydawnictwo Naukowe PWN, Warszawa 1995, s. 107.
} 
lasów i miast. Że stworzy nowe sposoby wyrażania naszej tożsamości i pozycji towarzyskiej"s.

Ewentualne zapobieżenie lub przynajmniej zminimalizowanie niebezpieczeństwa dominacji myślenia technologicznego nad kultura wymagałoby szerszego spojrzenia na całość życia społecznego, uwzględniającego wszystkie jego aspekty (w tym aksjologiczne), co jest zaprzeczeniem myślenia technicznego. Technokratyzm wywodzacy się ze scjentyzmu neguje nie tylko ważność, ale także możliwość takiego podejścia, promuje kształcenie i wychowanie zamykające człowieka $\mathrm{w}$ wąskiej specjalizacji, nie daje mu szerszego oglądu rzeczywistości, nie wyposaża go w kompetencje do wydawania sądów dotyczących czegoś więcej niż jego własna, wąsko pojęta specjalizacja zawodowa, a tym samym zaprzestaje kształcenia w nim kultury obywatelskiej.

$Z$ technokratycznego punktu widzenia kultura obywatelska nie jest zreszta we współczesnych społeczeństwach potrzebna, gdyż wybory, przed którymi stoja obywatele współczesnych państw nie polegaja na wybieraniu jednej $z$ wielu równoważnych możliwości, ale na zrozumieniu pewnej konieczności wskazującej tylko jeden kierunek działania. Wynika to $z$ przekonania, że tak naprawdę możliwe jest tylko jedno optimum, jedno właściwe rozwiąanie każdego problemu, jedna najlepsza wizja przyszłości. W tej sytuacji znika problem wyboru, chodzi jedynie o kompetencje pozwalajace to rozwiazanie dostrzec.

Technokrata sądzi, że „jedyna podstawa, aby uznać jakąś wizję przyszłości za konieczna do przyjęcia, za wizję obowiąująca, jest szczególna postać kompetencji merytokratycznej, mianowicie kompetencja $\mathrm{w}$ dziedzinie przyrodniczego oraz społecznego programowania. Polega ona na przewidywaniu głównie cząstkowych fenomenów, które jednak dadzą się razem ze sobą uzgodnić, by w efekcie końcowym złożyć się na całość świata zjawiskowego,

N. Postman: Zabawić się na śmierć. Dyskurs publiczny w epoce show-businessu, przekład L. Niedzielski, Wydawnictwo Muza, Warszawa 2002, s. 222. 
na podstawie pozytywistycznie czy scjentystycznie pojmowanych teorii i metod przyrodoznawstwa i nauk społecznych"6.

To przekonanie daje technokracie poczucie własnej nieomylności: „Technika i pewność siebie są dlań ze sobą nierozerwalnie zwiazane, bowiem wiedza pewna to, jego zdaniem, wiedza, która nie musi poza soba szukać gwarancji swej pewności; innymi słowy wiedza, która nie tylko kończy się na pewności, ale i od niej zaczyna i jest pewna w każdym punkcie" duje zbędność wszelkiej debaty dotyczacej tych zagadnień, Wszak „rozwiazanie zadań technicznych jest niezależne od publicznej dyskusji" . Skoro rozwiazania technokratyczne sa najlepsze (bo jedyne) - co jest oczywiste dla wszystkich, którzy sa w stanie je zrozumieć - dyskusja $z$ tymi, którzy nie potrafia tego dokonać, jest całkowicie zbędna. Jedyny wybór, jakiego się oczekuje od obywateli, to przekazanie prawa do podejmowania wyborów kompetentnym osobom.

Debata demokratyczna staje się więc, dla technokraty, pustym rytuałem, może jej potrzebować jako sposobu legitymizacji swoich poczynań, ale sama $\mathrm{w}$ sobie nie ma dla niego żadnego sensu. $Z$ jego punktu widzenia jest ona tylko strata czasu - jeżeli jej wynikiem są wnioski „właściwe” (to znaczy te, do których on wcześniej już doszedł) - lub też szkodliwym objawem głupoty (jeżeli dochodzi się w niej do konkluzji „złych”, to znaczy sprzecznych $z$ obiektywnym wynikiem analizy technologicznej). Jedynym sensem publicznej debaty dostrzegalnym dla technokraty jest jej funkcja edukacyjna: gdy podopieczni, pod czujnym okiem mistrza, uczą się, jak dochodzić do poprawnych wniosków. Poprawnych - należy to powtórzyć jeszcze raz - to znaczy takich, które on już wcześniej poznał i zaaprobował. Taka debata nie ma oczywiście nic wspólnego $z$ demokracja. „[...] demokracja potrzebna jest bowiem tam,

\footnotetext{
6 J. Kurczewska: Technokraci $i$ ich świat społeczny, Instytut Filozofii i Socjologii PAN, Warszawa 1997 , s. 18.

7 M. Oakeshott: Racjonalizm w polityce, przekład A Lipszyc, w: idem: Wieża Babel i inne eseje, Fundacja Aletheia, Warszawa 1999, s. 32.

8 J. Habermas: Technika i nauka jako „ideologia”, przekład M. Łukasiewicz, w: J. Szacki (red.): Czy kryzys socjologii?, Czytelnik, Warszawa 1977, s. 36.
} 
gdzie działamy $\mathrm{w}$ warunkach niepewności, gdzie liczymy na to, $\dot{z}$ e to, co rozumne dopiero wyłoni się $z$ debaty, ścierania się racji, wspólnego wysiłku. Założeniem roboczym demokracji jest, że każdy może się pomylić, zaś patentu na właściwe rozwiązania nie ma nikt, nawet ten, kto dysponuje jakąś ekspercka kompetencja”.".

Tymczasem technokrata, odwołując się do autorytetu dokonań techniki i nauki, uważa, że posiadana przezeń wiedza specjalistyczna jest tożsama $z$ wiedzą w ogóle, w tym ze „słusznością aksjologiczna"10. W tej sytuacji nie ma możliwości zakwestionowania postępowania rządu technokratycznego, nie będzie tego robił nikt $z$ technokratów, gdyż oni, rozumiejąc jego słuszność, nie maja powodu, by ja podważać; nie może tego zrobić też nikt inny, gdyż pozostali obywatele nie maja kompetencji, by oceniać decyzje technokratów. Co więcej, $z$ technokratycznego punktu widzenia, sam fakt ich zakwestionowania, a nawet wyrażenia odmiennego zdania, jest dowodem na brak takich kompetencji i/lub braku dobrej woli. W tej sytuacji niemożliwa jest jakakolwiek kontrola społeczna nad poczynaniami władzy.

Następstwa złożenia władzy w ręce jednej grupy społecznej, bez dania pozostałej części społeczeństwa realnych narzędzi kontroli, sa oczywiste. Społeczeństwo, w którym będzie dominować myślenie technokratyczne $\mathrm{w}$ nieunikniony sposób będzie się stawało społeczeństwem elitarystycznym, w którym jedna grupa będzie sprawować niekontrolowana władzę nad reszta pozostałych obywateli - oczywiście dla ich własnego dobra. Nierozstrzygnięty pozostaje jednak problem, na czym to dobro miałoby polegać.

Żadne współczesne społeczeństwo nie może funkcjonować bez ekspertów w każdej dziedzinie i bez wysokiej klasy specjalistów. Przed każdym przedsięwzięciem pojawia się problem skuteczności, która tylko oni moga zapewnić. Jednocześnie jednak często zapomina się, że nie ma czegoś takiego jak „po prostu skutecz-

9 A. Szahaj: Racjonalizm, technokratyzm $i$ śmierć polityki, w: J. Miklaszewska (red.): Rozum a porządek społeczny, Instytut Filozofii Uniwersytetu Jagiellońskiego, Kraków 2002, s. 65. ${ }_{10}$ Por. ibidem. 
ność", istnieje jedynie skuteczność w osiaganiu założonych celów. Technokracja tymczasem jest systemem „pustym” - sama $z$ siebie nie wyłania żadnych celów społecznych.

$Z$ jednej strony jest to zgodne $z$ postulatami liberalnymi, domagajacymi się neutralności państwa, $z$ drugiej może jednak prowadzić do przynajmniej trzech zagrożeń demokracji: możliwości kolaboracji technokratów $z$ rządem totalitarnym, odwołania się przez tę grupę do populizmu (to znaczy bezrefleksyjnego podporządkowania się żądaniom mas społecznych) oraz do próby samodzielnego sprawowania rządów poprzez demagogiczne podporządkowanie sobie głosu opinii publicznej.

\section{Technokratyzm i rządy totalitarne}

Technokrata przeważnie deklaruje się jako „bezpartyjny ekspert do wynajęcia”. W apologetycznej autodefinicji oznacza to tyle, że ekspert, nie mając własnych przekonań politycznych (lub separujac je od swojej działalności), potrafi współpracować z każda władza, wcielać w życie, w sposób możliwie optymalny, wszystkie wskazane przez nią cele.

Zjawisko to samo w sobie nie jest oczywiście wada - system sprawowania rządów nie powinien sam $z$ siebie wyznaczać celów, do których dąży społeczeństwo. Ogólne cele rząu powinny być wyznaczane $\mathrm{w}$ demokratycznej debacie, a następnie skutecznie wykonywane. Jednak wierność zasadom demokracji i podporząkowanie się woli większości nie znajduje uzasadnienia w światopoglądzie technokratycznym. Bezpośrednia konsekwencja tego jest, że „współpraca $z$ każda władza” może (choć nie musi) oznaczać również kolaborację $z$ władzą niedemokratyczną, a czasami wręcz totalitarną. Współpraca taka może być traktowana jako sposób na zwiększenie efektywności działania, na przyspieszenie koniecznych decyzji bez wdawania się w „czczą gadaninę”, typową dla systemów demokratycznych. 
Jest faktem, że wymóg skuteczności działania i „konieczność zapanowania nad ogólnym bałaganem" wielokrotnie były pretekstem do ograniczania, a nawet likwidacji demokracji w różnych państwach i uzasadnieniem dla sprawowania rządów niedemokratycznych. Technokratyzm, rozumiany jako konieczność planowania życia społecznego przez ekspertów, bywał często przywoływany przez marksistowskich ideologów jako uzasadnienie dyktatury $\mathrm{w}$ tak zwanych państwach realnego socjalizmu. A planowaniu podlegać mogło wszystko. Na przykład Jerzy Chłopecki pisał: „[...] sam rozwój demokracji socjalistycznej może i powinien chyba w większym niż dotąd stopniu być przedmiotem społecznego planowania. [...] planowanie rozwoju demokracji - analogicznie jak planuje się rozwój innych dziedzin życia społecznego - może zapewnić nadażanie rozwoju demokracji socjalistycznej za postępem osiaganym w innych dziedzinach"11.

We współczesnym świecie, wraz z rozwojem demokracji, problem współpracy $z$ reżimem totalitarnym ma jednak coraz mniejsze znaczenie. Również z tego względu, że technokrata, będąc gotowy przyjmować wskazówki od władzy odnośnie do celów, chce jednak być od niej niezależny, gdy chodzi o dobór środków koniecznych do ich osiagnięcia. Tymczasem władza totalitarna żąda podporządkowania całkowitego, a więc chce określać zarówno cele, jak i środki. W tej sytuacji systemy totalitarne po prostu nie znajduja w swych ramach miejsca dla technokratów - niezależnych specjalistów przyznających sobie prawo oceny postępowania rzadu. Wprawdzie ocena ta ma miejsce tylko w aspekcie skuteczności działań władzy, w osiaganiu wyznaczonych przez nią celów, a nie na przykład pod względem moralnym, ale i to byłoby wystarczającym podważeniem autorytetu władzy głoszacej swoja nieomylność. Władza totalitarna potrzebuje bowiem jedynie posłusznych wykonawców, a nie partnerów.

Paradoksalnie więc, o ile konsekwentny technokrata będzie miał skłonność do kolaboracji $\mathrm{z}$ rządem totalitarnym, stawiając jednak

$\overline{{ }^{11} \text { J. Chłopecki: Rewolucje i postęp, Państwowy Instytut Wydawniczy, Warszawa 1981, s. } 170 .}$ 
pewne warunki, o tyle właśnie sam fakt ich postawienia - pewna niezależność technokraty - spowoduje, że władza totalitarna nie będzie skłonna przyjać takiej oferty współpracy, a nawet nie będzie w ogóle tolerować postawy technokratycznej wśród swych obywateli.

\section{Technokratyzm i populizm}

Technologia (w tym technologia społeczna), będąc neutralna aksjologicznie, sama nie wskazuje celów, które za jej pomoca maja być osiagnięte, musi je więc traktować jako zastane. Jeżeli nie sa one narzucane przez rząd autokratyczny, technokrata może ich szukać w powszechnej opinii obywateli.

„Technokratyzm jest niebezpieczny także dlatego, że reakcja nań może być populizm, podejście, wedle którego lud ma zawsze rację, a to, co tzw. zwykli ludzie sądzą o świecie jest zawsze prawdziwe. A także bunt tych, którzy mając dość rządów ekspertów, moga zechcieć wziąć sprawy w swoje ręce. [...] Tylko wtedy, gdy unikniemy skrajności technokratyzmu, unikniemy także niebezpieczeństwa populizmu i buntu mas"12. Populizm w tym znaczeniu można traktować jako bezkrytyczną zgodę $z$ wyborem większości (oczywiście może to dotyczyć tylko wyboru celów, nigdy środków). Nawet jednak jeżeli populizm będziemy rozumieli w niepejoratywnym rozumieniu tego słowa, na przykład jako „typ polityki, której celem jest reprezentowanie interesów zwykłych ludzi ${ }^{13 "}$ czy - bardziej ogólnie - jako „wsparcie dla preferencji zwykłych ludzi”"14, prowadzi on zawsze do negatywnych skutków. Jego następstwem jest przekonanie, że polityk nie musi, a nawet nie powinien mieć własnego zdania na temat celów rządu. Demokracja to rządy ludu, rządy większości, polityk ma więc być jej przedstawicielem,

\footnotetext{
12 A. Szahaj: Racjonalizm..., s. 64

${ }^{13} \mathrm{~J}$. Crowther (red.): Oxford Advanced Learner's Dictionary of Current English, Oxford University Press, Oxford 1995, s. 867.

${ }^{14}$ I. McMillan (red.): The Concise Oxford Dictionary of Politics, Oxford University Press, Oxford 1997, s. 392.
} 
reprezentantem jej interesów. Nie może więc „pociagać za sobą mas, przedstawiając im wizje nowej przyszłości”, ale wręcz przeciwnie - nie powinien mówić, lecz słuchać. Jeżeli zaś już mówi, to $\mathrm{w}$ łatwej i przystępnej formie powinien zbierać to, co już usłyszał od „ludu”. Polityk, w tym ujęciu, będzie rozumiał swoja rolę nie jako „męża stanu”, ale raczej jako fachowca do wynajęcia, najemnika, który gotów jest profesjonalnie wykonywać wszystkie zlecenia pracodawcy (czyli w tym wypadku opinii publicznej), któremu zupełnie nie przeszkadza na przykład to, że pracodawca nieustannie zmienia zdanie, co uniemożliwia dokończenie jakichkolwiek długoterminowych zadań.

Takie rozwiazanie gwarantuje wprawdzie „neutralność aksjologiczną" technokraty względem celów społecznych, jednak, mimo swojej pozornej atrakcyjności, nie jest rozwiąaniem demokratycznym, w modelu tym bowiem technokrata w dalszym ciagu nie bierze udziału w publicznej debacie. Władza wykonuje zlecenia współobywateli, ale nie traktuje ich jak równych sobie. Zachowuje się tutaj raczej jak pobłażliwy ojciec spełniajacy zachcianki swojego rozkapryszonego dziecka. Przy zachowaniu pewnych zewnętrznych procedur demokratycznych utracone jest to, co w demokracji najważniejsze - wspólne decydowanie o losie państwa przez równych obywateli.

Ponadto niestabilność i zmienność opinii publicznej uniemożliwiaja de facto wykonanie jakikolwiek poważniejszych zadań oraz racjonalne rozplanowanie sił i środków. Uniemożliwiają zatem rządowi technokratycznemu sprawowanie tych funkcji, które są uzasadnieniem jego istnienia.

\section{Technokratyzm i demagogia}

Kwestia skuteczności rząu prowadzi do następnego problemu, często pomijanego w dyskusjach nad technokracja. Rzą technokratyczny jest neutralny tylko pozornie; wprawdzie może być 
neutralny wobec wartości, którymi kieruje się społeczeństwo, lecz nie wobec decyzji, które w nim zapadaja. Technokrata uważa się za "fachowca od "środków i metod", pracującego na rzecz jakiegoś zwierzchniego "demokratycznego organu decyzyjnego". Nie jest to jednak równoznaczne $z$ przekonaniem, że wszystkie decyzje władzy moga być wprowadzone w życie w sposób «naukowy", więc za pomoca określonej i z góry przyjętej techniki; znaczy to tylko tyle, że władza powinna robić tylko rzeczy, które do takiej techniki można sprowadzić"15.

$Z$ technokratycznego punktu widzenia decyzje demokratycznej władzy wyrażającej wolę większości obywateli nieuchronnie podlegaja pewnej ewaluacji: dziela się na dobre i złe, to znaczy takie, które podlegaja technicznej operacjonalizacji wedle wskazań racjonalności instrumentalnej oraz te, których wdrażanie nie może być równie skuteczne. Przy czym nie istnieje metoda pozwalająca uniknąc decyzji ( $z$ technologicznego punktu widzenia) błędnych, gdyż wymagaja one wiedzy dostępnej jedynie nielicznym ekspertom. W naturalny więc sposób pojawia się problem lojalności wobec ośrodka decyzyjnego ex definitione generującego błędne decyzje. Mówiąc inaczej - jeśli wiadomo, że ktoś nie potrafi podejmować właściwych decyzji, uprawnione jest pytanie: czy nie należałoby w jakiś sposób ograniczać jego prawa do ich podejmowania (oczywiście dla jego dobra).

Problem ten, stary jak demokracja, obecny jest również w tradycji liberalnej: „Masy - pisał John Stuart Mill - to znaczy zbiorowa miernota”"16, a „Rzad miernoty jest miernym rzacem”" ${ }^{17}$. W tej sytuacji jedynym warunkiem pomyślnego rozwoju społeczeństwa jest promowanie $\mathrm{w}$ jakiś sposób jednostek wybitnych, zdolnych do powstrzymywania tyranii mas: „Właśnie w tych okolicznościach należy nie odstraszać, lecz zachęcać wyjątkowe jednostki do postępowania odmiennie od mas"18.

\footnotetext{
${ }^{5}$ B. Crick: W obronie..., s. 144

${ }^{16}$ J.S. Mill: O wolności, w: idem: Utylitaryzm. O wolności, rzekład A. Kurlandzka, Wydawnictwo Naukowe PWN, Warszawa 2005, s 167.

${ }^{17}$ Ibidem, s. 168.

${ }^{18}$ Ibidem.
} 
Rodzi to paradoks: aby spełnić nadrzędny warunek skuteczności działania, być w pełni skutecznym wykonawca, technokrata nie może być jedynie wykonawca, lecz musi mieć realny wpływ nie tylko na dobór środków, ale także na wybór celów działania. Aby to osiagnać, powinien mieć zapewniony udział w rządzie. Nie może to jednak być rząd stricte demokratyczny, o którego kształcie wszyscy obywatele decyduja na równych prawach, lecz taki, w którym decydujący głos będa mieli ludzie mający odpowiednie kompetencje, czyli technokraci. Technokrata - w imię skuteczności działania - nie może więc zadowalać się rola jedynie posłusznego wykonawcy zaleceń władzy i nie ma żadnego znaczenia, czy będzie to władza demokratyczna, czy też autorytarna.

Technokratyzm $z$ natury swojej dąży więc do pełni władzy. Władza taka nie musi jednak być sformalizowana, chodzi przecież o realny wpływ na ważne decyzje rządu, a nie jego atrybuty zewnętrzne. Celem technokraty nie jest więc formalne zlikwidowanie demokracji i demokratycznego rządu, ale niezauważalne nim sterowanie. Najlepszym zaś sposobem odsunięcia współobywateli od wpływu na losy państwa, przy zachowaniu fasady demokracji, jest - jak pokazuja doświadczenia historyczne - demagogia.

Demagog bierze więc udział $\mathrm{w}$ debatach publicznych, jego celem nie jest jednak uzgodnienie wspólnego stanowiska, bioracego pod uwage opinie wszystkich zainteresowanych, ani nawet przeforsowanie własnej opinii (choć może to być jednym $z$ jego jego celów przejściowych $\mathrm{w}$ drodze do celu ostatecznego), ale przejęcie władzy.

Zgodnie ze słownikowa definicja demagog to „polityk, działacz, głoszący hasła obliczone na łatwy efekt, poklask, schlebiający masom, szafujący próżnymi obietnicami, budzacy nieziszczalne nadzieje, wysuwajacy w imieniu mas żądania nie do spełnienia"19. Demagog nie ma więc żadnych zahamowań w składaniu nierealistycznych deklaracji i obietnic, gdyż nie zamierza ich spełniać po dojściu do władzy. Debata publiczna jest dla niego czymśs

\footnotetext{
${ }^{19}$ W. Kopaliński: Słownik wyrazów obcych i zwrotów obcojęzycznych, Wiedza Powszechna, Warszawa 1990, s. 112.
} 
ważnym jako konieczny środek przejęcia władzy, lecz nie wynika $z$ tego wymóg poważnego traktowania swoich wypowiedzi, majacych charakter tylko narzędny.

Zdobyta władzę technokrata chce spożytkować dla dobra ogółu. Wprawdzie nie wierzy w jakąkolwiek wspólność natury ze swoimi rodakami, ale uważa, że ma $z$ nimi pewien wspólny cel - pomyślność i rozwój państwa, narodu czy społeczeństwa. W ramach dażenia do tego celu każdy ma swoje typowe, tylko dla siebie przeznaczone miejsce. Ci, którzy mają odpowiednie kompetencje powinni przewodzić, tłum (masa) powinien iść za nimi. Zasadnicza różnica między politykiem a reszta obywateli polega na tym, iż polityk-technokrata odmawia im zdolności do zrozumienia racjonalnych argumentów, a co za tym idzie - zdolności do podjęcia właściwych decyzji.

„Mamy tu [...] do czynienia $z$ taką samą odwieczna różnica jak ta, która dzieli ludzi na głupich i mądrych. [....] Nie chodzi o to, że człowiek masowy jest głupi. Wręcz przeciwnie, jest bystrzejszy i ma większe zdolności intelektualne niż jego poprzednicy w jakiejkolwiek innej epoce. Ale zdolności te do niczego mu nie służa; co więcej, niejasne poczucie, że je posiada, prowadzi jedynie do tego, że jeszcze szczelniej zamyka się w sobie, zupełnie ich nie wykorzystujac. Raz na zawsze uznaje za święty zbiór komunałów, szczątków idei, przesąów czy po prostu pustych słów, które za sprawa przypadku nagromadził w swoim wnętrzu, by potem ze śmiałościa, która wytłumaczyć można tylko naiwnym prostactwem, narzucać je innym. To właśnie uznałem [...] za cechę charakterystyczną dla naszych czasów: nie to, że człowiek pospolity wierzy, iż jest jednostką nieprzeciętna, a nie pospolitą, lecz to, że żąda praw dla pospolitości czy wręcz domaga się tego, by pospolitość stała się prawem" ${ }^{20}$.

W technokracji polityk zgodziłby się całkowicie $z$ przytoczona opinia José Ortegi y Gasseta, uznając, przy tym, że jest to stan

${ }^{20}$ J. Ortega y Gasset: Bunt mas $i$ inne pisma socjologiczne, przekład P. Niklewicz, H. Woźniakowski, Państwowe Wydawnictwo Naukowe, Warszawa 1982, s. 78-79. 
niereformowalny: „Durnia nie sposób wyrwać z objęć własnej głupoty"21. Bezcelowe więc byłoby marnowanie sił i środków na daremne próby podniesienia go na wyższy poziom. Taki stan trzeba zaakceptować oraz wyciagnać wnioski, to znaczy mówić do „ludu” językiem dla niego zrozumiałym, językiem tłumu odwołującym się nie do racjonalnych argumentów, ale do emocji, namiętności, stereotypów i uprzedzeń.

Celem debaty publicznej - w rozumieniu technokratów - nie jest podjęcie właściwych decyzji, lecz jedynie uzyskanie (wszelkimi środkami) przyzwolenia, by decyzje te były pozostawione w rękach polityków. Demagogia jest więc sposobem delikatnego pozbawienia ludzi tego, czego oni i tak nie potrafią właściwie użyć, czegoś, co byłoby dla nich niebezpieczne. Tak jak troskliwy ojciec delikatnie wyjmuje $z$ rąk dziecka ostre narzędzia, którymi mogłoby się skaleczyć, nie podając jednocześnie prawdziwych powodów swego postępowania, gdyż uważa, że dziecko nie jest w stanie ich pojąć.

Rezygnacja $\mathrm{z}$ języka racjonalnego $\mathrm{w}$ kontaktach $\mathrm{z}$ "masami” nie oznacza jednak rezygnacji $z$ języka racjonalnego $w$ ogóle. Chodzi tylko o ograniczenie jego zakresu, traktowanie go jedynie jako języka „wewnętrznego", służącego do formułowania celów na własny użytek i - ewentualnie - porozumiewania się wyłącznie w kręgu wtajemniczonych. Nie ma jednego uniwersalnego języka, z każdym trzeba się porozumiewać językiem skrojonym na miarę jego możliwości, dlatego językiem „wewnętrznym” jest logika, językiem „zewnętrznym” zaś demagogia i retoryka. W dalszym ciagu są one jednak ściśle zhierarchizowane - język „wewnętrzny” jest lepszy, bo może służyć do prawdziwego opisania rzeczywistości, drugi język służy tylko do „schlebiania gustom motłochu”. Analogicznie do sytuacji opisanej przez Orwella w Roku 1984, demagog-technokrata, nawet jeśli posługuje się drugim językiem w kontaktach międzyludzkich, musi przez cały czas myśleć za pomoca pierwsze-

${ }^{21}$ Ibidem, s. 79. 
go. Celem kontaktów politycznych nie jest włączenie jak największej liczby ludzi w działalność obywatelska, lecz przeciwnie - celem jest wyłączenie ich poza nawias życia publicznego przy zachowaniu pozorów uczestnictwa. Demokracja jest tu raczej zawada przy realizowaniu prawdziwie ważnych zadań społecznych, gdyż dopuszcza do współrządzenia ludzi, którzy nie sa w stanie pojąc takowych przedsięwzięć. Demagogia jest więc metoda na pobicie demokracji jej własna bronią i niezauważalne rozciagnnięcie paternalistycznej opieki nad niezbyt rozgarniętym społeczeństwem.

\section{Technokraci - nowa arystokracja}

Paternalistyczne społeczeństwo może sprawnie funkcjonować (choć raczej będzie chodziło o trwanie, a nie o rozwój) przynosząc pożytek obywatelom, jednak tylko pod warunkiem, że elity społeczne $\mathrm{w}$ pełni utożsamiają się $z$ resztą społeczeństwa oraz że pomyślność społeczna stanowi istotna część ich osobistej motywacji (jest to konieczne przy braku możliwości sprawowania realnej kontroli społecznej nad elitami). Podobnie jak feudalna arystokracja rodowa uważała się za lepsza pod każdym względem od reszty społeczeństwa, ale jednocześnie za część swojego etosu uważała (przynajmniej teoretycznie) opiekę nad owa słabsza częścią.

Współczesna elitę społeczeństwa stanowia nie tylko przywódcy społeczni i polityczni oraz zarzadzajacy korporacjami przemysłowo-finansowymi, ale $\mathrm{w}$ coraz większym stopniu przedstawiciele zawodów tworzacych i manipulujących informacjami. Jest charakterystyczne, że wraz $z$ postępem globalizacji wszyscy oni czują się w coraz mniejszym stopniu związani ze społecznościami, $z$ których się wywodzą. Christoper Lasch, analizując przekonania dominujące $\mathrm{w}$ tej grupie, przeciwstawia ją właśnie arystokracji. Zdaniem tego autora główną cechą współczesnej elity społeczeństw zachodnich jest jej kosmopolityzm - wyobcowanie ze społeczeń- 
stwa, w którym (a właściwie obok którego) przyszło jej żyć. Lasch przeciwstawia im "stara arystokrację ” - bogate rodziny, zasiedziałe od pokoleń w jednym miejscu, które, przekonane, że „bogactwo pociaga za sobą obowiązki obywatelskie"22, oprócz gromadzenia majątku zajmowały się również filantropią. Mimo że motywy tego bardzo często były egoistyczne „Naprawdę liczyło się jednak to, że filantropia angażowała elity $\mathrm{w}$ życie sassiadów oraz przyszłych pokoleń" ${ }^{23}$.

Tymczasem „nowe elity sa u siebie tylko w drodze”24, nigdzie nie maja domu rozumianego jako miejsce, za które czujemy się odpowiedzialni i związek z którym przynajmniej częściowo określa naszą tożsamość. Współczesny rynek pracy wymusza niesłychana mobilność, której cena jest zerwanie wszelkich ściślejszych więzi międzyludzkich. Jedyne naprawdę istniejące kontakty ograniczone sa do wasko pojętej rodziny (choć wraz ze wzrastająca liczba rozwodów nawet ona traci charakter stałego punktu odniesienia) oraz do równie wasskiej grupy wysoko wyspecjalizowanych profesjonalistów należących do tej samej klasy społecznej. „Cenę tę płaca chętnie, gdyż pojęcie domu kojarzy im się ze wścibskimi krewnymi i sassiadami, małoduszna plotka i zacofanymi konwencjami. Nowe elity buntują się przeciw "środkowej Ameryce", tak jak ja sobie wyobrażaja - krajowi technologicznie zacofanemu, politycznie staroświeckiemu, o represyjnej moralności seksualnej, niewyszukanym smaku, zadufanemu i zadowolonemu $\mathrm{z}$ siebie, nudnemu i nieciekawemu"25.

Lasch odwraca tezę Buntu mas argumentując, że obecnie to właśnie elity społeczne sa bliższe „człowiekowi pospolitemu” tak jak go przedstawiał Ortega y Gasset, natomiast wierności tradycji i resztek cnót obywatelskich należy szukać wśród „zwykłych ludzi”. „Według poglądu Ortegi - szeroko wówczas podzielanego

\footnotetext{
${ }^{22}$ Ch. Lasch: Bunt elit, przekład D. Rodziewicz, Wydawnictwo Platan, Kraków 1997, s. 13.

${ }^{23}$ Ibidem, s. 14

${ }^{24}$ Ibidem, s. 15

25 Ibidem.
} 
- wartość elit kulturalnych polega na chęci przyjmowania odpowiedzialności za surowe normy, bez których niemożliwa jest cywilizacja. Żyły one w służbie wymagających ideałów. "Szlachectwo określają wymagania i obowiązki, a nie przywileje»"26. Przeciwieństwem elity jest masa, ludzie pospolici, którzy po prostu nie maja poczucia jakichkolwiek wyższych powinności, ich cecha charakterystyczna jest „ponad wszystko to, że "masa śmiertelnie nienawidzi wszystkiego, co nie jest nią samą". Człowiek masowy, niezdolny do odczuwania szacunku lub zdziwienia, jest rozpuszczonym dzieckiem dziejów ludzkości. Wszystkie tego typu nastawienia umysłowe są obecnie [...] bardziej charakterystyczne dla wyższych niż niższych czy średnich warstw społeczeństwa”27. Elity „zachowuja wiele wad arystokracji, nie posiadając jej cnót"28.

Proces ten, zdaniem Lascha, powoduje "nowy trybalizm” - rozpad społeczeństwa na grupy mające ze soba niewiele wspólnego. Jednym $z$ zarówno przejawów, jak i źródeł kryzysu demokracji, o którego istnieniu Lasch jest głęboko przekonany, jest fakt, że obecnie wszelkie grupy społeczne (dotyczy to oczywiście przede wszystkim elit) rozmawiaja wyłącznie same ze soba za pomoca odrębnych języków, niezrozumiałych dla osób nie należących do danego środowiska.

Jeżeli diagnoza Lascha jest trafna - to znaczy proces alienacji elit posunął się na tyle daleko, że nie poczuwaja się one do związków $z$ reszta obywateli - pod znakiem zapytania stoi przekonanie stanowiące (chyba jedyne) usprawiedliwienie rządów paternalistycznych, mianowicie, że władza może się nie pytać społeczeństwa (podopiecznych) o zdanie, gdyż, w pełni się z nim utożsamiając, doskonale je rozumie (zapewne nawet lepiej niż reszta współobywateli) oraz $\mathrm{w}$ pełni podziela cele tego społeczeństwa. Jeśli tego zabraknie (a zdaniem Lascha $z$ takim zjawiskiem mamy już do czynienia), zdobyta władza może niezwykle szybko stać

\footnotetext{
${ }^{26}$ Ibidem, s. 33

${ }^{27}$ Ibidem, s. 34

${ }^{28}$ Ibidem, s. 50.
} 
się celem samym w sobie. Nie darmo do kanonu przekonań liberalnych należy przekonanie, że „władza absolutna korumpuje absolutnie".

W tym momencie koło się zamyka - technokratyzm, zaczynajac jako próba ułatwienia życia obywatelom, niezwykłe łatwo może się przeistoczyć w uzasadnienie panowania nad nimi. 